\title{
Isolation and Antimicrobial Resistance of Escherichia coli and Salmonella enterica subsp. enterica $(0: 6,8)$ in Broiler Chickens*
}

\author{
Windleyanne Gonçalves Amorim Bezerra', Isaac Neto Goes da Silva², Ruben Horn Vasconcelos', \\ Débora Nishi Machado', Elisângela de Souza Lopes', Suzan Vitória Girão Lima',

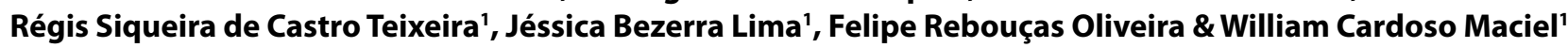

\begin{abstract}
Background: The third largest poultry flock in Northeast Brazil is located in Ceará State. Some pathogens are commonly disseminated in broiler chicken flocks, such as the bacteria from the Enterobacteriaceae family. Among these, some strains of Escherichia coli are frequently associated with different pathological manifestations in domestic animals, while bacteria from the genus Salmonella are considered the most frequent enteric pathogens reported causing foodborne infections in humans. Therefore, this study aimed to evaluate the prevalence and antimicrobial resistance of Salmonella sp. and Escherichia coli strains isolated from broiler chickens in the Metropolitan Region of Fortaleza city, Brazil.

Materials, Methods \& Results: Samples were collected from July-2014 to March-2015 in ten broiler chicken farms located in the Metropolitan Region of Fortaleza city, Brazil, with birds in pre-slaughter age. From each farm, 100 individual cloacal swabs were randomly collected from broilers independent of clinical status. Distinct methodologies were used in order to provide optimal isolation conditions for both the bacterial species. For Escherichia coli, the methodology consisted in enrichment with BHI broth, plating in EMB agar and biochemical identification, after which some isolates were maintained in nutrient agar for antimicrobial resistance evaluation. For the isolation of Salmonella sp., a standard method was used with pre-enrichment, selective enrichment, selective plating and biochemical identification steps. Antimicrobial susceptibility test (AST) was performed with disk diffusion technique and the following antibiotics were tested: ampicillin, ceftiofur, ciprofloxacin, trimethoprim-sulfamethoxazole, polymyxin B, gentamycin, cloranfenicol, tetracycline, azithromycin and fosfomycin. According to the methodology used, $95.9 \%$ of samples were positive for Escherichia coli and the most frequent resistance was to trimethoprim-sulfamethoxazole. Salmonella sp. was isolated from $0.2 \%$ of the samples, which were identified as the serotype Salmonella enterica subsp. enterica O:6,8. Both isolates presented the same antimicrobial resistance profile, which were resistant to six, out of ten tested antibiotics (trimethoprim-sulfamethoxazole, tetracycline, ciprofloxacin, azithromycin, chloramphenicol and ceftiofur).

Discussion: The low prevalence of Salmonella observed in this study have also been reported by other studies performed in poultry farms in Ceará State, which suggests a good status for this pathogen in the local industry, however further efforts in order to eradicate this pathogen must be applied. The salmonella serotype detected in this study is rarely reported in the literature, especially from the poultry industry. In Brazil, the use of tetracyclines, quinolones and penicillins as feed additives or growth promoters is prohibited; however, a high resistance to drugs from these groups was detected. In addition, multidrug resistant $E$. coli isolates presented more elevated rates than other studies reported in the literature with antibiotics commonly used in the poultry industry and this may indicate an excessive use of these drugs in the production routine. These results should serve as a warning for surveillance programs to evaluate the incidence of these microorganisms as well as their antimicrobial resistance rates, which may be an important tool for control and prevention in meat poultry production.
\end{abstract}

Keywords: antibiotic, multidrug resistance, poultry industry. 


\section{INTRODUCTION}

Brazil is the third largest producer of poultry meat in the world, close behind of United States and China. However, it is the leading exporter and $69.8 \%$ of the total volume of broiler chicken production is destined for domestic market, while $30.2 \%$ is exported [35]. The third largest poultry flock in Brazilian Northeast region is located in Ceará State, with 28.3 million birds [16].

Some pathogens are easily disseminated in poultry flocks due to the high density of birds in rearing, such as the members of Enterobacteriaceae family, which are distributed worldwide and may be found in soil, water, fruits, vegetables, grains, flowers, trees and animals [15]. Escherichia coli is a member of the intestinal microbiota of some birds, however some strains are frequently associated with several pathological manifestations in domestic animals related to environmental conditions and management practice $[10,11,17]$. Bacteria from the genus Salmonella are the most common enteric pathogens associated with foodborne infections originated from poultry products consumed by humans, but also responsible for severe economic losses [14].

Both bacterial species present adaptive capacity that favors persistence in bird flocks and outbreaks recurrence, which enhances the importance of studying the behavior of these microorganisms for public and animal health sake. In this context, bacterial resistance to antibiotics represent a serious problem of clinical and public health concern, since scientific evidence indicate that the use of these drugs in animals destined to human consumption is possibly the main cause of emergence and distribution of resistant strains [1,33]. Therefore, this study aimed to evaluate the prevalence of Salmonella sp. and Escherichia coli in broiler chickens from the Metropolitan Region of Fortaleza and the antimicrobial resistance of the isolated strains.

\section{MATERIALS AND METHODS}

\section{Samples}

Sampling was performed from July-2014 to March-2015 in ten broiler chicken farms located in the Metropolitan Region of Fortaleza city, Brazil, with birds in pre-slaughter age (35 to 38 days). From each farm, 100 individual cloacal swabs were randomly collected, independent of clinical status of the birds.
Samples were transported in microtubes containing 300 $\mu \mathrm{L}$ of Brain Heart Infusion (BHI) ${ }^{1}$ broth refrigerated in isothermal box containing recyclable ice and sent to the Laboratory of Ornithological Studies (LABEO) located in the State University of Ceará (UECE) in Fortaleza, Brazil.

\section{Bacteriological procedure}

Distinct methodologies were used in order to provide optimal conditions of isolation for both bacterial species. For the isolation of Escherichia coli, a previously described methodology [18] was used with modifications. Briefly, after arriving at LABEO, $200 \mu \mathrm{L}$ of the BHI suspension used for sample transportation was incubated, after which a loopful of the suspension was streaked in plate containing EMB Levine agar ${ }^{1}$. Colonies with morphological characteristics (dark colored colonies with a brilliant sheen) of E. coli were selected and submitted to identification with the following biochemical tests: Triple-Sugar-Iron agar (TSI) ${ }^{2}$, Lysine-Iron-Agar (LIA) ${ }^{2}$, Sulfide-Indole-Motility agar $(\mathrm{SIM})^{2}$, Citrate $^{2}$, Malonate ${ }^{2}$, Voges-Proskauer ${ }^{2}$ and Methyl $\mathrm{Red}^{2}$. Part of the isolates from each farm after biochemical confirmation were maintained in nutrient agar for evaluation of phenotypic antimicrobial resistance.

For the isolation of Salmonella sp., recommendations from the Brazilian Ministry of Agriculture, Livestock and Supply (MAPA) [6] were followed with modifications. Briefly, the following procedure was performed: immediately after arriving in LABEO, aliquots of $100 \mu \mathrm{L}$ were transferred from BHI with samples to microtubes containing $1 \mathrm{~mL}$ of buffered peptone water ${ }^{2}$. After incubation, $10 \mu \mathrm{L}$ and $100 \mu \mathrm{L}$ were respectively transferred to microtubes containing $1 \mathrm{~mL}$ of the broths Rappaport-Vassiliadis and Selenite-Cystine added $40 \mu \mathrm{g} / \mathrm{mL}$ of Novobiocin ${ }^{3}$ and then incubated. Afterwards, samples were streaked in at least two solid selective media: Brilliant Green agar ${ }^{2}$ added Novobiocin ${ }^{3}(40 \mu \mathrm{g} / \mathrm{mL})$ and Hektoen Enteric agar $^{2}$ or Salmonella-Shigella ${ }^{1}$ agar. After incubation, two to three colonies from each sample with morphological characteristics compatible with Salmonella sp. were submitted to biochemical identification with the following tests $\mathrm{TSI}^{2}, \mathrm{LIA}^{2}$ and urea broth ${ }^{4}$. In all bacteriological incubation steps, standard temperature was $37^{\circ} \mathrm{C}$ in bacteriological incubator and the duration was $24 \mathrm{~h}$. Isolates with biochemical profile compatible with Salmonella spp. were tested with polyvalent 
antiserum $\mathrm{O}^{5}$ in a rapid slide agglutination test and when positive were sent to the reference Laboratory of Enterobacteria (LABENT) located in FIOCRUZ/RJ for serotype identification.

Phenotypic antimicrobial resistance

Antimicrobial susceptibility test (AST) was performed in the isolates with the disk diffusion method [4]. The following antibiotic disks ${ }^{1}$ with respective concentrations were used: ampicillin $(10 \mu \mathrm{g})$, ceftiofur (30 $\mu \mathrm{g})$, ciprofloxacin $(5 \mu \mathrm{g})$, trimethoprim-sulfamethoxazole $(25 \mu \mathrm{g})$, polymyxin B (300 U.I.), gentamycin (10 $\mu \mathrm{g})$, chloramphenicol $(30 \mu \mathrm{g})$, tetracycline $(30 \mu \mathrm{g})$, azithromycin $(15 \mu \mathrm{g})$ e fosfomycin $(200 \mu \mathrm{g})$. Inhibition zone diameters were measured and values were interpreted according to manufacturer's specifications and to standards established by the Clinical and Laboratory Standards Institute (CLSI) [8].

\section{RESULTS}

According to the methodology used in this study, 95.9\% were positive for Escherichia coli from a total of 1000 samples analyzed. Antimicrobial susceptibility testing revealed that all $E$. coli strains studied were resistant to trimethoprim-sulfamethoxazole and the following resistance rates were registered: tetracycline (95.4\%), ciprofloxacin (91.4\%), ampicillin $(87.3 \%)$, chloramphenicol $(51.1 \%)$, azithromycin (48.8\%) ceftiofur (42.5\%), fosfomycin (33.3\%), gentamycin $(27.6 \%)$ and polymyxin B (1.1\%) [Figure 1].

Results showed that $98.3 \%$ (171/174) of the tested $E$. coli strains were resistant to three or more antibiotics from different drug groups, while most strains $(24.7 \%)$ were resistant to five, out of ten tested antimicrobials, and no isolate was susceptible to all of the antibiotics. The maximum number of antibiotics to which a single strain presented resistance was nine, out of ten tested, which occurred in eight isolates (Table 1).

Salmonella was isolated from $0.2 \%(2 / 1000)$ of individual cloacal swab samples from a single farm. According to the reference laboratory, the two isolates were identified as Salmonella enterica subsp. enterica O:6,8 and neither presented flagellar structure. At the time of collection, we observed that some birds were apparently healthy, while others presented respiratory, intestinal and/or locomotor clinical signs and birds from which the Salmonella strains were isolated presented some of these symptoms. AST results showed the same antimicrobial resistance profile for both isolates, which were resistant to six, out of ten tested antibiotics: trimethoprim-sulfamethoxazole, tetracycline, ciprofloxacin, azithromycin, chloramphenicol and ceftiofur (Table 2).

Table 1. Multi-drug resistance of Escherichia coli isolated from broiler chickens.

\begin{tabular}{cc}
\hline Number of antibiotics & Resistant E. coli isolates $(\%)$ \\
\hline None & $0(0 \%)$ \\
1 & $0(0 \%)$ \\
2 & $3(1.7 \%)$ \\
3 & $17(9.8 \%)$ \\
4 & $28(16.0 \%)$ \\
5 & $43(24.7 \%)$ \\
6 & $39(22.4 \%)$ \\
7 & $18(10.4 \%)$ \\
8 & $18(10.4 \%)$ \\
9 & $8(4.6 \%)$ \\
10 & $0(0 \%)$ \\
\hline
\end{tabular}

Table 2. Antimicrobial resistance profiles of Salmonella enterica subsp. enterica $(\mathrm{O}: 6,8)$ isolates from cloacal swab samples of broiler chickens.

\begin{tabular}{|c|c|c|c|c|c|c|c|c|c|c|}
\hline \multirow{2}{*}{ Isolate } & \multicolumn{10}{|c|}{ Antibiotics } \\
\hline & CIP & $\mathrm{GEN}$ & AZI & AMP & TET & SUT & CLO & CTF & POL & FOS \\
\hline $\begin{array}{c}\text { Salmonella enterica subsp. } \\
\text { enterica }(\mathrm{O}: 6,8)\end{array}$ & $\mathrm{R}$ & $\mathrm{S}$ & $\mathrm{R}$ & $\mathrm{S}$ & $\mathrm{R}$ & $\mathrm{R}$ & $\mathrm{R}$ & $\mathrm{R}$ & $\mathrm{S}$ & $\mathrm{S}$ \\
\hline $\begin{array}{c}\text { Salmonella enterica subsp. } \\
\text { enterica }(\mathrm{O}: 6,8)\end{array}$ & $\mathrm{R}$ & $\mathrm{S}$ & $\mathrm{R}$ & $\mathrm{S}$ & $\mathrm{R}$ & $\mathrm{R}$ & $\mathrm{R}$ & $\mathrm{R}$ & $\mathrm{S}$ & $\mathrm{S}$ \\
\hline
\end{tabular}




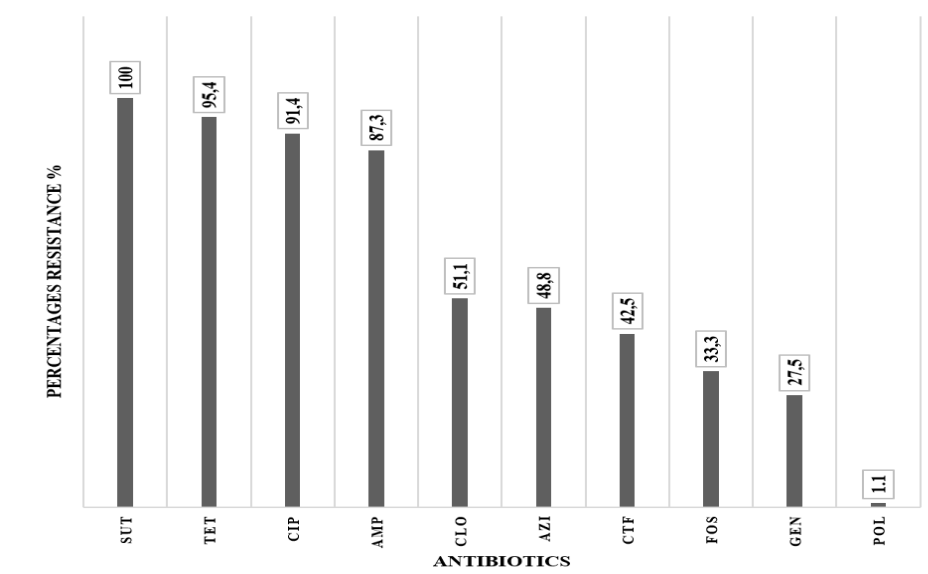

Figure 1. Antimicrobial resistance of $E$. coli isolated from broiler chickens to 10 antibiotics tested individually using disk diffusion method.

\section{DISCUSSION}

A low prevalence of Salmonella was detected in this study, which have been reported by other authors in surveys performed in the local poultry industry of Ceará State, where this pathogen was not isolated from the feces of ten broiler chicken flocks [24]. However, a rough strain of Salmonella enterica subsp. enterica and Salmonella Newport were isolated from 32 samples from feces of layer hens, while no strain was isolated from 40 meconium samples of layer chicks, also showing low prevalence rates [31]. Recently, a study revealed that $0.58 \%$ out of 510 broiler day-old chicks sampled from hatcheries located in Ceará State were positive for Salmonella Enteritidis, which indicates that birds may arrive in farms already infected [2]. The low prevalence of Salmonella sp. reported in this study as well as in other studies suggest a good status of this pathogen in the local poultry industry, however further efforts to eradicate this pathogen should be reinforced. There are scarce reports about the serotype of salmonella detected in this study. A single study [26] reported one strain $(0.1 \%)$ from 207 strains of salmonella isolated from drag swab samples collected from litter of broiler chicken farms in Goiás and São Paulo State, which may indicate that this serotype is rare, possibly emergent, or even it is hard to isolate with conventional methods.

An elevated resistance rate to trimethoprimsulfamethoxazole $(100 \%)$ was found in this study; however, a lower result (28\%) has been reported in 69 E. coli strains isolated from feces of healthy broiler chicken [28]. A study performed with 91 cloacal swab samples from healthy broiler chickens revealed a con- siderably high resistance rate to this antibiotic $(68.1 \%)$ [34], which was similar to another report with 86 E. coli strains isolated from air sacs of birds with respiratory signs and identified a $66.7 \%$ of isolates resistant to this antibiotic association [7]. However, a study performed in Pernambuco State with 16 E. coli from cecal content of healthy broiler chickens revealed a low resistance rate to trimethoprim-sulfamethoxazole (43.7\%) when compared to the present study, while 13 birds that presented clinical signs of respiratory disease revealed a high resistance rate $(84.6 \%)$ [3]. In addition, recent studies verified elevated resistance in $25 \mathrm{E}$. coli isolates from cloacal swab samples of healthy broiler chickens to the same antibiotic (84\%) [2], unlike what was observed with 60 feces samples of intensive reared broiler chickens, which revealed $45 \%$ of resistance to trimethoprim-sulfamethoxazole [19].

The use of tetracyclines, quinolones and penicillins as feed additives or growth promoters in broiler chickens is prohibited in Brazil [6], however this study found high resistance rates to drugs from these groups (tetracycline, ciprofloxacin and ampicillin). Similar findings were recently found in E. coli samples from feces of broiler chickens reared in intensive system in the Metropolitan Region of Curitiba with the following rates, respectively $83 \%, 23 \%$ and $100 \%$ [19]. A previous study [28] revealed lower resistance rates to tetracycline (48\%) and ampicillin (42\%) when compared to this study, while another study showed higher values in E. coli samples, which $67 \%$ were resistant to tetracycline and $84.6 \%$ were resistant to ampicillin [34]. In Canada, the antimicrobial resistance profiles of $600 \mathrm{E}$. coli isolates from broiler chickens was identified and high antimicrobial resistance 
rate to tetracycline (69.2\%) was found, however no resistance to ciprofloxacin was identified [21]. These findings reveal that bacterial resistance to antibiotics should be constantly monitored due to the variation observed during time and in different geographic locations.

Multidrug resistance rates found in E. coli samples from this study were higher than other reports, which identified in $65.7 \%$ (46/70) of analyzed strains [28] and $81.6 \%$ (49/60) in isolates from intensive reared broiler chickens. However, a multidrug resistance rate of $94.2 \%(33 / 35)$ in isolates that were resistant to three or more antibiotics from different groups was reported [3], which is a value closer to the result found in this study. Therefore, studies found in the literature along with this research show worrying rates of resistance to antibiotics commonly used in poultry industry, which may indicate an excessive use of these drugs in the production routine.

As for the resistant Salmonella, the low number of isolates in this study may not reflect the real situation in the studied population and recent studies with a higher number of isolates show different results. However, a low resistance rate to tetracycline $(30.8 \%)$ have been reported in 39 Salmonella isolates from broiler farms sampled with drag swabs and none was resistant to ciprofloxacin [25]. Studies with AST in 18 strains of Salmonella isolated from drag swabs of poultry in São Paulo State showed $100 \%$ susceptibility of serotypes to chloramphenicol and tetracycline, with a low resistance rate to trimethoprim-sulfamethoxazole (11\%) [13]. In addition, resistance profile of 53 Salmonella isolates from poultry origin to different antibiotics in Goiás State revealed elevated sulfonamide resistance rates $(73.6 \%)$, while trimethoprim-sulfamethoxazole and tetracycline were low, both with $13.2 \%$, followed by ampicillin and enrofloxacin, both with $5.7 \%$ [23]. These authors found higher values of resistance to the antibiotics most commonly used in poultry industry, which was also identified in this study.

Ceftiofur is a third generation cephalosporin, which is a group of drugs used to treat humans with salmonellosis, which is worrying that both Salmonella isolates in this study were resistant. However, other studies reported low resistance rates to this antibiotic, such as $15.4 \%$ (2/13) in Salmonella isolates from cloacal swab samples of broiler chickens [5]. In addition, 250 Salmonella isolates from frozen chicken carcasses in fifteen Brazilian cities, including Fortaleza, revealed that $28 \%$ were resistant to ceftiofur [21]. Antimicrobial resistance of salmonella isolates to ceftiofur is constantly reported and public health concern has increased the interested in this type of study [9].

Although MAPA prohibits the use of chloramphenicol since 1998 in Brazil, resistance to this drug in both bacterial species was registered. This finding was reported in a study [28], in which E. coli isolated from the intestinal microbiota of chickens in conventional rearing system at different ages presented high resistance rate to chloramphenicol (52\%) and the authors related this to the presence of resistance genes present in some plasmids. In another study, the antimicrobial resistance profiles of 19 different Salmonella sp. serotypes from broiler chickens in Paraná State was identified and revealed that $51 \%$ of serotypes were resistant to at least one of the tested drugs, among which chloramphenicol and gentamycin presented the lowest rates $(2.6 \%)$ [25].

\section{CONCLUSION}

This study reports the occurrence of multidrug resistant E. coli isolates, as well as the existence of multiresistant Salmonella enterica subsp. enterica $(\mathrm{O}: 6,8)$ in the intestinal microbiota of broiler chickens in farms located in Fortaleza, Brazil. These results should serve as a warning for surveillance programs to monitor the incidence and antimicrobial resistance of these microorganisms, which may be an important tool for control and prevention in meat poultry production.

\section{MANUFACTURERS}

${ }^{1}$ Cefar - Home. São Paulo, SP, Brazil.

${ }^{2}$ HiMedia Laboratories. Mumbai, India.

${ }^{3}$ Sigma-Aldrich Chemie GmbH. Munich, Germany.

${ }^{4}$ Difco Laboratories Inc. Franklin Lakes, NJ, USA.

${ }^{5}$ Probac do Brasil®. São Paulo, SP, Brazil.

Acknowledgments. We thank the Laboratory of Ornithological Studies (LABEO/FAVET/UECE) for the technical support and CEFAR Company that kindly provided culture media for microbiological diagnosis and antimicrobial disks for susceptibility tests.

Funding. During the experiment, the first author had a doctoral scholarship provided by the Fundação Cearense de Apoio ao Desenvolvimento Científico e Tecnológico (FUNCAP).

Ethical approval. The experimental protocol was approved by the Ethics Committee for Animal Use of the State University of Ceará (CEUA/UECE) protocol 2183725/2014.

Declaration of interest. The authors report no conflicts of interest. The authors alone are responsible for the content and writing of the paper. 


\section{REFERENCES}

1 Angulo F.J., Johnson K., Tauxe R.V. \& Cohen M. 2000. Significance and sources of antimicrobial-resistant nontyphoidal Salmonella infections in the United States. Microbial Drug Resistance. 6(1): 77-83.

2 Albuquerque A.H., Cardoso W.M., Lopes E.S., Teixeira R.S.C., Salles R.P.R., Machado D.N., Bezerra W.G.A., Vasconcelos R.H., Mendonça S.V. \& Carbó C.B. 2014. Presence of Salmonella spp. in One-day-old Chicks from Hatcheries in the Metropolitan Region of Fortaleza, Brazil. Acta Scientiae Veterinariae. 42(1222): 1-7.

3 Barros M.R., Silveira W.D., Araujo J.M., Costa E.P., Oliveira A.A.F., Santos A.P.S.F., Silva V.A.S. \& Mota R.A. 2012. Resistência antimicrobiana e perfil plasmidial de Escherichia coli isolada de frangos de corte e poedeiras comerciais no Estado de Pernambuco. Pesquisa Veterinária Brasileira. 32(5): 405-410.

4 Bauer A.W., Kirby W.M.M., Sherris C.J. \& Turck M. 1966. Antibiotic susceptibility testing by a standardized single disk method. American Journal of Clinical Pathology. 45(4): 493-496.

5 Borsoi A., Santin E., Santos L.R., Salle C.T.P., Moraes H.L.S. \& Nascimento V.P. 2009. Inoculation of newly hatched broiler chicks with two Brazilian isolates of Salmonella Heidelberg strains with different virulence gene profiles, antimicrobial resistance, and pulsed field gel electrophoresis patterns to intestinal changes evaluation. Poultry Science. 88(4): 750-758.

6 Brasil, Ministério da Agricultura, Pecuária e Abastecimento. 2003. Instrução Normativa ${ }^{\circ} 62$ de 26 agosto de 2003. Métodos Analíticos Oficiais para Análises Microbiológicas para Controle de Produtos de Origem Animal e Água. Diário Oficial da República Federativa do Brasil, Poder Executivo, Brasília, DF, 18 setembro, 2003. Seção I, 14-50.

7 Cardoso A.L.S.P., Tessari E.N.C., Castro A.G.M. \& Zanatta G.F. 2002. Avaliação da susceptibilidade a antimicrobianos de cepas de Escherichia coli de origem aviária. Arquivo do Instituto Biológico. 69(2): 1-5.

8 Clinical Laboratory Standards Institute. 2012. Document M2-A11 - Performance Standards for Antimicrobial Disk Susceptibility Tests; Approved Standard - Eleventh Edition. v.32, n.1.15p.

9 Colla F.L., Rodrigues L.B., Borsoi A., Dickel E.L., Nascimento V.P. \& Santos L.R. 2012. Isolamento de Salmonella Heidelberg em diferentes pontos da tecnologia de abate de frangos de corte. Arquivo do Instituto Biológico. 79(4): 603-606.

10 Dho-Moulin M. \& Fairbrother J.M. 1999. Avian pathogenic Escherichia coli (APEC). Veterinary Research, 30(2-3): 299-316.

11 Ferreira A.J.P. \& Knöbl T. 2009. Colibacilose. In: Berchieri Jr. A., Silva E.N., Fábio J., Sesti L. \& Zuanaze M.A.F. (Eds). Doenças das aves. 2.ed. Campinas: Fundação APINCO de Ciência e Tecnologia Avícolas, pp.457-471.

12 Gambiragi A.P.O.M., Salles R.P.R., Aguiar Filho J.L., Oliveira W.F., Cardoso W.M., Romão J.M. \& Teixeira R.S.C. 2003. Salmonella sp. em frangos de corte de um dia de idade na Região Metropolitana de Fortaleza-CE. Acta Scientiae Veterinariae. 31(3): 149-153.

13 Galdino V.M.C.A., Melo Roberta T., Oliveira R.P., Mendonça E.P., Nalevaiko P.C. \& Rossi D.A. 2013. Virulência de Salmonella spp. de origem avícola e resistência a antimicrobianos. Bioscience Journal. 29(4): 932-939.

14 Hafez H.M. 2005. Perspectiva global de enfermidades emergentes e re-emergentes em aves. In: Conferência Apinco 2005 de Ciência e Tecnologia Avícolas (Santos, Brasil). pp.123-138.

15 Holt J.G., Krieg N.R., Sneath, P.H.A., Staley J.T. \& Williams S.T. 1994. Bergey's Manual of Determinative Bacteriology. 9th edn. Baltimore: Williams \& Wilkins, 787p.

16 Instituto Brasileiro de Geografia e Estatística (IBGE). 2013. Produção da Pecuária Municipal 2013. Disponível em: <http://www.ibge.gov.br >. [Accessed September 2015].

17 Johnson J.R. 1991.Virulence factors in Escherichia coli urinary tract infection. Clinical Microbiology Reviews. 4(1): 80-128.

18 Koneman E.W., Allen S.D., Janda W.M., Schreckenberger P.C., Winn Jr. W.C. \& Cury A.E. 2001. Diagnóstico microbiológico: texto e atlas colorido. 5.ed. Rio de Janeiro: Medsi, 1488p.

19 Korb A., Nazareno E.R., Costa L.D., Nogueira K.S., Dalsenter P.R., Tuon F.F.B. \& Pomba M.C. 2015. Tipagem molecular e resistência aos antimicrobianos em isolados de Escherichia coli de frangos de corte e de tratadores na Região Metropolitana de Curitiba, Paraná. Pesquisa Veterinária Brasileira. 35(3): 258-264.

20 Mainali C., Mcfall M., King R. \& Irwin R. 2013. Evaluation of antimicrobial resistance profiles of Escherichia coli isolates of broiler chickens at slaughter in Alberta, Canada. Journal of Food Protection. 76(12): 2045-2051.

21 Medeiros M.A.N., Oliveira D.C.N., Rodrigues D.P. \& Freitas D.R.C. 2011. Prevalence and antimicrobial resistance of Salmonella in chicken carcasses at retail in 15 Brazilian cities. Revista Panamamericana de Salud Publica. 30(6): 555-560. 
22 Mohamed M.A., Shehata M.A. \& Rafeek E. 2014. Virulence genes content and antimicrobial resistance in Escherichia coli from broiler chickens. Veterinary Medicine International. 2014(195189): 1-6.

23 Moraes D.M.C., Andrade M.A., Minafra-Rezende C.S., Barnabé A.C.S., Jayme V.S., Nunes I.A. \& Batista D.A. 2014. Fontes de infecção e perfil de suscetibilidade aos antimicrobianos de Salmonella sp. isoladas no fluxo de produção de frangos de corte. Arquivo do Instituto Biológico. 81(3): 195-201.

24 Oliveira W.F., Maciel W.C., Marques L.C.L., Salles R.P.R., Aguiar Filho J.L.C., Teixeira R.S.C., Romão J.M. \& Lima A.C.P. 2004. Utilização de diferentes meios de cultura para o isolamento de enterobactérias em amostras fecais de frango de corte procedentes de exploração industriais do Estado do Ceará, Brasil. Revista Portuguesa de Ciências Veterinárias. 99(522): 211-214.

25 Pandini J.A., Pinto F.G.S., Muller J.M., Weber L.D. \& Moura A.C. 2015. Ocorrência e perfil de resistência antimicrobiana de sorotipos de Salmonella spp. isolados de aviários do Paraná, Brasil. Arquivo do Instituto Biológico. 82: 1-6.

26 Paschoal Cardoso A.L.S., Kanashiro A.M.I., Stoppa G.F.Z., Castro A.G.M., Luciano R.L. \& Tessari E.N.C. 2013. Prevalência de Salmonella Enteritidis isolada de suabes de arrasto em granjas de frango de corte. Revista Científica Eletrônica de Medicina Veterinária. 20: 1-15.

27 Pereira V.L.A., Silva G.M. \& Lemos M. 1999. Presença de Salmonella em frangos de corte aparentemente sadios em unidades de criação industrial na região de São José do Vale do Rio Preto - RJ. Revista Brasileira de Ciências Veterinárias. 6(3): 156-161.

28 Pessanha R.P. \& Gontijo Filho P.P. 2001. Uso de antimicrobianos como promotores de crescimento e resistência em isolados de Escherichia coli e de Enterobacteriaceae lactose-negativa da microflora fecal de frangos de corte. Arquivo Brasileiro de Medicina Veterinária e Zootecnia. 53(1): 60-64.

29 Pickler L., Hayashi R.M., Lourenço M.C., Miglino L.B., Caron L.F., Beirão B.C.B., Silva A.V.F. \& Santin E. 2012. Avaliação microbiológica, histológica e imunológica de frangos de corte desafiados com Salmonella Enteritidis e Minnesota e tratados com ácidos orgânicos. Pesquisa Veterinária Brasileira. 32(1): 27-36.

30 Ravagnani L.K., Agostinis R.O., Otutumi L.K., Lima E.T., Fernandes J.I.M. \& Martins L.A. 2012. Pesquisa de Salmonella spp. em frangos de corte criados em galpões climatizados de uma integração na região Oeste do Paraná. Semina. 33(6): 2327-2336.

31 Salles R.P.R., Teixeira R.S.C., Siqueira A.A., Silva E.E., Castro S.B. \& Maciel W.C. 2008. Monitoramento bacteriológico para Salmonella spp. em poedeira comercial na recria e produção de empresas avícolas da Região Metropolitana de Fortaleza. Ciência Animal Brasileira. 9(2): 427-432.

32 Santos L.A., Mion L., Marotzki M., Parizotto L., Rodrigues L.B., Nascimento V.P. \& Santos L.R. 2015. Número mais provável miniaturizado e microbiologia convencional para isolamento de Salmonella spp. em abatedouros de frangos de corte. Pesquisa Veterinária Brasileira. 35(3): 223-229.

33 Silva E.N. \& Duarte A. 2002. Salmonella Enteritidis in poultry: retrospective in Brazil. Revista Brasileira de Ciência Avícola. 4(2): 85-100.

34 Stella A.E., Vitor T.L., Gadelha D.F.B.G., Moreira C.N., Meirelles-Bartoli R.B. \& Oliveira A.F. 2013. Escherichia coli resistente a antimicrobianos isolada de bovinos e aves. Ars Veterinaria. 29(4): 14.

35 União Brasileira de Avicultura (UBABEF). 2012. Relatório Anual. Disponível em: <http://www.uba.org.br>. [Accessed September 2013].

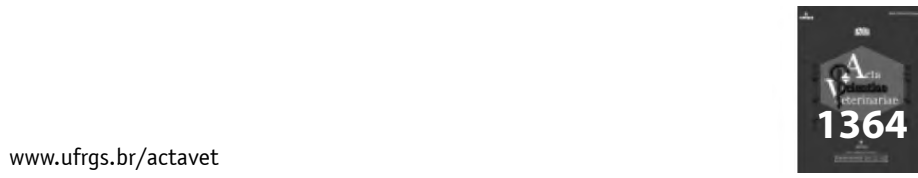

